\title{
EFFECTIVE DEMAND FOR SELECTED CULTURAL EVENTS IN SLOVAKIA
}

\author{
[Efektívny dopyt po vybraných kultúrnych podujatiach na Slovensku]
}

\author{
Kristína Pompurová ${ }^{1}$ \\ ${ }^{1}$ Univerzita Mateja Bela, Ekonomická fakulta, Tajovského 10, 97590 Banská Bystrica, SR \\ Email: kristina.pompurova@umb.sk
}

\begin{abstract}
Tourism events represent a dynamic element of the destination primary offer, which can increase the region's competitiveness. Destination stakeholders seek in hosting the tourism events augmentation of destination visitation, furthermore, it helps to overcome the seasonality, to enhance the destination marketing and to sustain a positive development of the region. The study investigates Slovak citizens' effective demand for three selected cultural events. The study findings are based on primary sources analysis of data collected via questionnaire survey as well as on domestic and foreign literature.
\end{abstract}

Keywords: concert, cultural events, effective demand, festival, tourism.

JEL classification: L83, M31

Doručeno redakci: 6.6.2013; Recenzováno: 10.6.2013; 24.6.2013; Schváleno k publikování: 16.6.2014

\section{Úvod}

V ekonómii sa dopyt po určitom tovare alebo službe definuje ako „súhrn relatívne samostatných rozhodnutí spotrebitel'ov o požadovanom množstve a kvalite v závislosti od cien“ (Muchová, 2003, s. 76). Inak povedané, je „súhrnom všetkých statkov a služieb, požadovaných zo strany spotrebitel'ov pri danej cene“" (Horehájová, Marasová, 2007, s. 42). Vyjadruje teda vzájomný vzt’ah medzi množstvom požadovaných tovarov a služieb a ich cenou. Paulička a iní (2002, s. 760, heslo Dopyt) pritom upozorňujú na podmienku kúpyschopnosti a dopytom rozumejú na trhu manifestovanú potrebu určitých tovarov a služieb, „pre ktorých uspokojenie existujú použitel’né peniaze“. Potreba, ktorá ostáva pre nedostatok disponibilných prostriedkov len túžbou sa označuje ako latentný dopyt. Kým sa kúpyschopný dopyt konkrétne neprejaví, ostáva potenciálnym. Po uskutočnení kúpy hovoríme o efektívnom dopyte.

Explicitné definície dopytu po cestovnom ruchu nie sú v dostupnej literatúre početné, vychádzajú predovšetkým z ekonomického vymedzenia dopytu. Napr. renomovaní autori Hunziker a Krapf (1942 In Gúčik, 2010, s. 102) dopytom po cestovnom ruchu rozumejú komplexný systém vzt'ahov zameraných na statky a služby, ktoré sa návštevníci snažia získat' pri určitej cenovej hladine. Kaspar (1995, s. 86) ho chápe ako ochotu návštevníka zamenit' isté množstvo statkov cestovného ruchu za určité množstvo peňazí. Frechtling (2012) dopyt po cestovnom ruchu vymedzuje ako mieru použitia tovarov a služieb návštevníkmi.

Autori publikácií o cestovnom ruchu sa na rozdiel od ekonomickej teórie nesústred’ujú len na množstvo požadovaných produktov cestovného ruchu, ale aj na počet spotrebitel'ov, t. j. návštevníkov ako nositel'ov dopytu po cestovnom ruchu. Swarbrooke a Horner (2001, s. 24) uvádzajú, že dopyt po cestovnom ruchu má niekol'ko dimenzií, v najjednoduchšom zmysle ide o počet návštevníkov v určitom území (regióne, štáte, vo svete). Frechtling (2012) sa zmieňuje, že dopyt po cestovnom ruchu môže byt' vyjadrený v heterogénnych jednotkách, počnúc národnou menou (hodnotenie príjmov od návštevníkov), cez príchody a prenocovania návštevníkov, pobytové dni, až po precestovanú vzdialenost' či obsadenie kapacít. Lim (1997) 
konštatuje, že najčastejšie sa pri vymedzení agregátneho dopytu po cestovnom ruchu v určitom území používa počet návštevníkov.

Vyjadrenie dopytu počtom návštevníkov je možné vd’aka viazanosti produktu cestovného ruchu na ciel'ové miesto (stredisko, región, štát). Spotreba väčšiny služieb v cestovnom ruchu predpokladá, že návštevník príde do určitého ciel'ového miesta, aby ich mohol spotrebovat'. Svoj dopyt po statkoch a službách návštevníci v cestovnom ruchu demonštrujú prítomnost'ou v ciel'ovom mieste. Rovnako tak robia aj návštevníci organizovaných podujatí, ktoré sú v cestovnom ruchu považované za dynamickú súčast' primárnej ponuky ciel'ového miesta, schopnú podnietit' cestovanie, predĺžit' pobyt v ciel'ovom mieste, zmiernit' sezónnost', generovat' dodatočné príjmy a d'alšie pozitívne ekonomické účinky pre dané územie.

Ako sa zmieňuje Getz (2012), dopyt návštevníkov po organizovaných podujatiach má niekol'ko osobitostí a od dopytu po cestovnom ruchu sa čiastočne líši. Vyplýva to najmä zo skutočnosti, že podujatie sa na trhu predáva, resp. ponúka ako zážitok, nie ako konkrétna služba. Vzt’ah medzi množstvom požadovaných tovarov a služieb a ich cenou preto v prípade podujatí nemožno explicitne vyjadrit'. Univerzálne aplikovatel'né nie je ani ekonomické vymedzenie, ktoré dáva do pomeru množstvo požadovaných podujatí a ich cenu, a to z dôvodu, že vstup na niektoré druhy podujatí je zdarma, prípadne je dotovaný. Cena teda nemusí byt' kl'účovým faktorom dopytu po podujatiach. Pre potenciálnych návštevníkov býva t’ažké kvantifikovat' množstvo peňazí, ktoré by boli ochotní zaplatit' za zážitok ako službu. Marketéri preto zaviedli koncept ponuky hodnoty. Tá porovnáva, akú cenu je ciel'ový trh ochotný zaplatit' za vstup na podujatie v porovnaní s referenčným produktom, napr. o kol'ko viac alebo menej je ochotný zaplatit' za vstupenku na koncert alebo hudobný festival v porovnaní s cenou hudobného nosiča (referenčný bežnejší produkt). Ked’že účast' na podujatí možno stotožnit' s obstaraním, resp. kúpou zážitku, je potrebné zdôraznit' jej vysokú substituovatel'nost' a v prípade platených podujatí aj vysokú cenovú elasticitu. Dopredu predvídat' počet návštevníkov podujatia je preto značne náročné. Rovnako zložité je aj jeho matematické modelovanie.

Podobne ako v prípade dopytu po cestovnom ruchu, aj dopyt po podujatiach sa najčastejšie vyjadruje počtom návštevníkov, prípadne aj výškou ich výdavkov alebo precestovanou vzdialenost'ou. Ked’že oficiálne štatistiky nesledujú informácie o počte návštevníkov podujatí, agregátny dopyt návštevníkov po organizovaných podujatiach je problematické kvantifikovat'. Väčšina autorov preto skúma čiastkový dopyt, t. j. dopyt po vybraných podujatiach (festivaloch, obchodných podujatiach alebo športových podujatiach svetového významu). Autori pritom pracujú s informáciami získanými primárnym prieskumom, ktorým zist'ujú analogické údaje ako v prípade dopytu po cestovnom ruchu (socio-demografické charakteristiky osôb, motív návštevy, správanie návštevníkov). Priestor teda dostávajú kvalitatívne znaky dopytu.

\section{Ciel' a materiál skúmania}

Ked'že dopyt po organizovaných podujatiach je vel'mi diferencovaný, rozhodli sme sa preskúmat' uspokojený dopyt po vybraných podujatiach. Našim ciel'om bolo zhodnotit' a porovnat' efektívny dopyt po vybraných podujatiach na Slovensku. Z hl'adiska obsahového zamerania sme sa zamerali na kultúrne podujatia, ktoré sú v cestovnom ruchu najviac navštevované. Ďalším faktorom ovplyvňujúcim výber podujatí bola ich dlhšia existencia (tradícia), ročná periodickost', rôzny význam a možnost' oslovenia návštevníkov, ktorí sa ich v minulosti zúčastnili. Zamerali sme sa preto na analýzu uspokojeného dopytu po hudobnom festivale Bažant Pohoda, ktorý patrí k podujatiam s národným významom, ako aj analýzu dopytu po Festivale satiry a humoru Kremnické Gagy, ktorý má prevažne regionálny význam. 
Prostredníctvom vyškolených anketárov sme v prvom štvrt'roku 2013 uskutočnili primárny prieskum. Dotazníkom sme oslovili 154 respondentov, ktorí sa v minulosti zúčastnili hudobného festivalu Bažant Pohoda v Trenčíne a 100 respondentov, ktorí navštívili Festival satiry a humoru Kremnické Gagy v Kremnici. Informácie o dopyte po podujatí miestneho významu „Tanečný koncert“, sme získali zo sekundárnych zdrojov (Fuzáková Dvorožňáková, 2009).

Vzhl'adom na malý rozsah výberového súboru a absenciu informácii o základnom súbore sú získané dáta len orientačné a nie je možné ich zovšeobecnit'. Vyhodnotili sme ich opisnou štatistikou.

\section{Výsledky skúmania}

\subsection{Festival Bažant Pohoda}

Do prieskumu uspokojeného dopytu po hudobnom festivale bažant Pohoda sa zapojilo 154 respondentov. Prevažnú čast' (75,3 \%) tvorili ženy, ktoré sú vo všeobecnosti ochotnejšie participovat' na dotazníkových prieskumoch. Viac ako polovica $(57,8 \%)$ respondentov bola vo veku 15 až 24 rokov, 29,2 \% malo 25 až 34 rokov, 10,4 \% 35 až 44 rokov. Staršie vekové kategórie boli vzhl'adom na charakter organizovaného podujatia menej zastúpené (45 až 54 roční respondenti: $1,95 \%, 55$ až 64 roční respondenti: $0,7 \%$ ).

Väčšina respondentov $(71,4 \%)$ dané podujatie navštívila po prvý krát. Takmer každý tretí respondent $(27,3 \%)$ sa na ňom v minulosti jeden- alebo dvakrát zúčastnil, väčší počet (tri až štyri) minulých návštev uviedlo len $1,3 \%$. Predpokladáme, že dôvodom je predovšetkým vysoká priemerná cena vstupenky na podujatie, prípadne aj miesto konania podujatia, resp. jeho vzdialenost' od miesta obvyklého pobytu návštevníkov.

$\mathrm{Na}$ festival prišla viac ako polovica (51,3 \%) z nich s priatel'mi a známymi, 33,8 \% s partnerom, 5,8 \% s rodinnými príslušníkmi a 5,2 \% s kolegami. Len 3,9 \% respondentov prišlo na festival samo, z čoho vyplýva, že účastníci festivalu sa radi o zážitky z kultúrneho podujatia delia s blízkymi l'ud'mi.

Len $11,7 \%$ respondentov uviedlo, že Trenčín, na ktorého letisku sa podujatie koná, je ich obvyklým miestom pobytu, t. j. že v ňom bývajú, pracujú alebo študujú. Účast' na festivale bola hlavným motívom návštevy Trenčína pre 79,2 \% respondentov, 9,1 \% pricestovalo do Trenčína primárne za iným účelom. Dominanciu hlavného motívu návštevy cielového miesta si vysvetl'ujeme predovšetkým v súvislosti s významom daného podujatia, ktoré je viacerými portálmi hodnotené ako jeden z najlepších európskych hudobných festivalov ${ }^{1}$.

Väčšina respondentov (92,2 \%) svoju účast' na danom podujatí dopredu dôsledne plánovala. Len $7,8 \%$ sa o návšteve podujatia rozhodlo bezprostredne, čo predpokladáme, súvisí s náhodným získaním vstupeniek (napr. výhra v sútaži, dar, odkúpenie vstupeniek od osôb, ktoré sa podujatia nemohli zúčastnit' ap.).

Kým polovica $(50,6 \%)$ respondentov sa o účasti na festivale rozhodovala v časovom predstihu jedného až dvoch mesiacov, pätina (19,5\%) sa o návšteve podujatia rozhodla osem až 14 dní vopred a $11,7 \%$ dokonca viac ako dva mesiace dopredu, čo súvisí s diferenciáciou cien vstupeniek podl'a času kúpy. Len 7,8 \% sa rozhodlo navštívit' festival jeden až tri dni

\footnotetext{
${ }^{1}$ V roku 2012 sa festival Bažant Pohoda podl'a European Festival Awards umiestnil na siedmom mieste $\mathrm{v}$ kategórii najlepší stredne vel’ký európsky festival. V hodnotení prestí̌neho servera Virtualfestivals.com získal v roku 201210 bodov z 10 .
} 
pred jeho konaním, 6,5 \% sa rozhodlo štyri až sedem dní vopred a 3,9 \% v deň jeho uskutočnenia. Predpokladáme, že išlo predovšetkým o jednotlivcov, ktorí vstupenku na podujatie získali náhodne.

Obrázok 1: Časový predtih rozhodovania o účasti na festivale

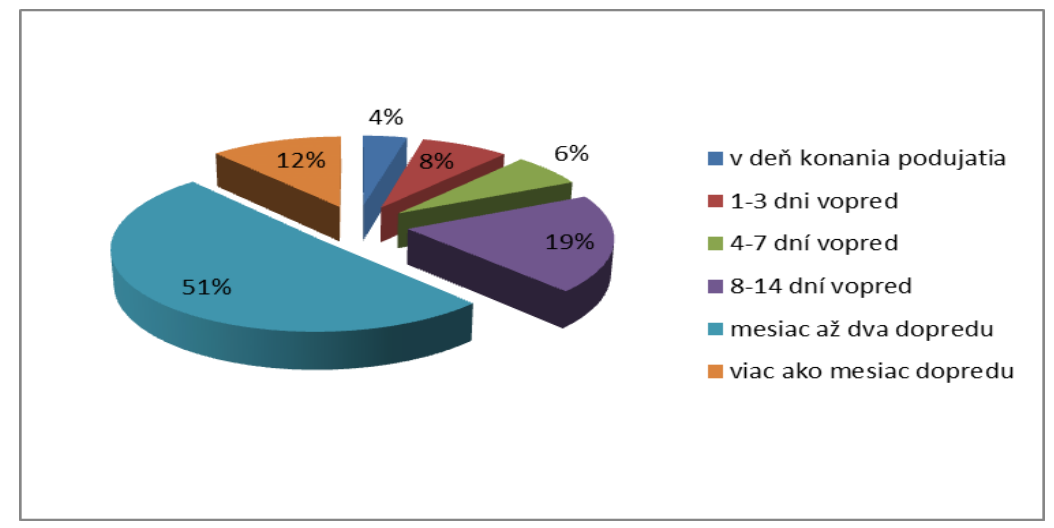

Zdroj: Vlastné spracovanie, 2013.

K rozhodujúcim motívom účasti na hudobnom festivale patrilo (1) sledovanie vystúpení spevákov a hudobných skupín, (2) jedinečnost' podujatia a (3) kultúrne obohatenie a objavovanie. Zriedkavejšie sa respondenti podujatia zúčastnili kvôli (4) neopakovatel'nej atmosfére či (5) socializácii.

Hlavným zdrojom informácii o festivale boli pre $27,9 \%$ respondentov príbuzní, priatelia a známi, pre 18,8 \% televízia, resp. reklama v televízii a pre 18,2 \% vlastná predchádzajúca skúsenost'. Až 16,9 \% respondentov sa o festivale primárne dozvedelo z vonkajšej reklamy, $10,4 \% \mathrm{z}$ rádia a len $7,8 \% \mathrm{z}$ internetu. Konštatujeme teda, že v prípade festivalu Bažant Pohoda sa jeho účastníci o podujatí dozvedajú prevažne $\mathrm{z}$ externých zdrojov, $\mathrm{v}$ rámci ktorých dominujú elektronické zdroje (televízia, rádio, internet), nasledované spoločenskými zdrojmi (príbuzní, priatelia, známi).

Obrázok 2: Zdroj informácií o festivale

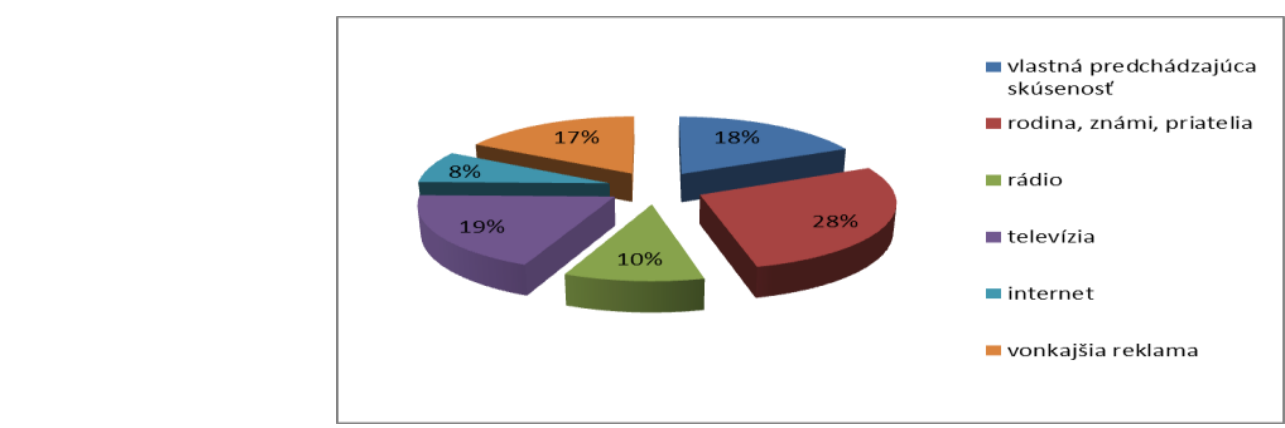

Zdroj: Vlastné spracovanie, 2013.

Vstupenku na podujatie si väčšina (80,5 \%) respondentov kúpila u sprostredkovatel'ov $(64,9$ \% cez Ticketportal, 6,5 \% v turistickej informačnej kancelárii, 5,8 \% v kníhkupectve a 3,2 \% cez portál Atrfórum), približne pätina (19,5 \%) dostala vstupenku ako darček, resp. získala ju iným spôsobom (napr. výhra v sút'aži, výmena za iné vstupenky ap.), čo potvrdzuje prestíž daného podujatia. 
Viac ako polovica $(50,7 \%)$ respondentov si vstupenku na podujatie zakúpila za viac ako 50 eur, štvrtina $(24,7 \%)$ za cenu od 40 do 50 eur, pätina (19,5\%) dostala vstupenku zdarma. Len nepatrný podiel respondentov (5,20 \%) získal zl'avnenú vstupenku do 40 eur. Usudzujeme, že išlo o zdravotne znevýhodnených jednotlivcov, prípadne ich sprievod, resp. osoby, ktoré využili ponuku kúpy vstupenky prostredníctvom mobilného operátora.

Najväčší podiel respondentov $(27,3 \%)$ precestoval z miesta svojho obvyklého pobytu do miesta konania podujatia 21 až $50 \mathrm{~km}$, rovnaký podiel precestoval 101 až $200 \mathrm{~km}$. Takmer pätina (18,2\%) respondentov precestovala 201 až $500 \mathrm{~km}, 13 \%$ jednotlivcov precestovalo 51 až $100 \mathrm{~km}, 10,4$ \% vzdialenost' menšiu ako $20 \mathrm{~km}$ a 3,9 \% viac než $501 \mathrm{~km}$. Predpokladáme, že išlo o osoby, ktoré študujú alebo pracujú v zahraničí. Konštatujeme, že kým 50,6 \% respondentov prekonalo kvôli účasti na festivale najviac 100 km, zvyšných 49,4 \% cestovalo viac ako $100 \mathrm{~km}$.

Najčastejšie sa pritom respondenti z miesta svojho obvyklého pobytu prepravili osobným automobilom (40,3\%), za ktorým nasledoval vlak (27,3\%), autobus (18,2\%), motocykel $(8,4$ $\%)$. Iba 4,5 \% respondentov sa na festival dostalo pešo a $1,3 \%$ na bicykli. Usudzujeme, že išlo o obyvatel'ov žijúcich, resp. študujúcich alebo pracujúcich v blízkosti Trenčianskeho letiska, prípadne o respondentov, ktorí majú v mieste organizovania podujatia priatel'ov, príbuzných alebo známych. V súvislosti s využitím osobného automobilu pritom návštevníci museli rátat' so zaplatení parkovného (v predpredaji, prípadne priamo na mieste).

Respondenti, ktorí sa obvykle nezdržiavajú v Trenčíne počas festivalu prenocujú predovšetkým v stanovom mestečku v mieste konania podujatia $(82 \%)$, v menšej miere u príbuzných a priatel'ov (16,2 \%), v hoteli alebo penzióne $(1,5 \%)$. Ked’že väčšina jednotlivcov prenocovala v stanovom mestečku (ubytovanie v stanoch zdarma) alebo u príbuzných a známych, na ubytovacie služby nevynaložili žiadne finančné prostriedky. Výnimkou sú tí, ktorí sa rozhodli pre ubytovanie v hoteli alebo penzióne, za ubytovacie služby pritom zaplatili viac než 50 eur.

Počas festivalu respondenti vynaložili na stravovacie služby najčastejšie od 40 do 50 eur $(31,2$ $\%)$, viac ako 50 eur $(29,9 \%)$ a od 30 do 40 eur $(27,9 \%)$. Len 5,2 \% minulo na stravovacie služby od 20 do 30 eur, $3,9 \%$ od 10 do 20 eur a 1,9\% maximálne 10 eur (tabul'ka 1 ).

Na dopravu respondenti najčastejšie vynaložili od 20 do 30 eur (27,3\%), prípadne neminuli žiadne finančné prostriedky (21,4 \%). Predpokladáme, že išlo o jednotlivcov, ktorí prišli peši, na bicykli alebo automobilom spolu s priatel'mi alebo príbuznými. Pätina (19,5\%) zaplatila za dopravu od 10 do 20 eur, $13 \%$ minulo na dopravu od 40 do 50 eur, 9,7\% do 10 eur (predpokladáme, že využili kyvadlovú dopravu), 5,8 \% od 30 do 40 eur a 3,2\% viac než 50 eur. Predpokladáme, že išlo o jednotlivcov, ktorí pracujú alebo študujú v zahraničí a na podujatie pricestovali z väčšej vzdialenosti.

Až 96,7 \% respondentov vynaložilo peňažné prostriedky na kúpu suveníru (tričká, CD, odznaky, čiapky, bundy, prívesky, plagáty ap.), najčastejšie pritom minuli 10 až 20 eur (37,7 $\%)$. Na kultúrne a spoločenské vyžitie počas pobytu v mieste konania podujatia spotrebovalo peňažné prostriedky $12,3 \%$ respondentov. Len $0,65 \%$ respondentov malo aj iné výdavky, spojené s adrenalínovým skokom na gumenom lane $\mathrm{v}$ areáli miesta konania festivalu (tabul'ka $1)$. 
Tabul'ka 1: Výdavky respondentov na účast' na festivale Bažant Pohoda

\begin{tabular}{|l|c|c|c|c|c|c|c|}
\hline \multirow{2}{*}{ Výdavky na } & \multicolumn{6}{|c|}{ Podiel respondentov v \%, ktorí na podujatie vynaložili } \\
\cline { 2 - 8 } & $0 €$ & do $10 €$ & do $20 €$ & do $30 €$ & do $40 €$ & do $50 €$ & nad $50 €$ \\
\hline vstupenku & 19,48 & 0,00 & 0,00 & 1,30 & 3,90 & 24,68 & 50,65 \\
občerstvenie/ stravovanie & 0,00 & 1,95 & 3,90 & 5,19 & 27,92 & 31,17 & 29,87 \\
ubytovanie & 98,70 & 0,00 & 0,00 & 0,00 & 0,00 & 0,00 & 1,30 \\
dopravu & 21,43 & 9,74 & 19,48 & 27,27 & 5,84 & 12,99 & 3,25 \\
suveníry & 3,25 & 27,27 & 37,66 & 14,94 & 15,58 & 1,30 & 0,00 \\
kultúrne a spoločenské vyžitie & 87,66 & 0,00 & 1,95 & 3,25 & 1,95 & 1,95 & 3,25 \\
iné & & & & & & & \\
\hline Spolu & 99,35 & 0,00 & 0,00 & 0,00 & 0,00 & 0,00 & 0,65 \\
\hline
\end{tabular}

Zdroj: Vlastné spracovanie, 2013.

Až 92 \% opýtaných minulo na účast' na festivale Bažant Pohoda viac ako 50 eur. Ak berieme do úvahy štruktúru výdavkov (tabulka 1), predpokladáme, že väčšina respondentov vydala na vstupenku, stravu, dopravu a spomienkové predmety približne 100 eur, čo zodpovedá prieskumu, ktorý v roku 2011 zrealizovala Slovenská sporitel’ňa (Bažant Pohoda: Návštevník minie na festivale $\mathrm{v}$ priemere $40 €$, www.slsp.sk, 2011). Podl'a daného prieskumu minie návštevník festivalu v priemere 50 eur na vstupenku, 10 eur na cestovné a 40 eur na d'alšie výdavky počas festivalu, t. j. spolu 100 až 110 eur. Korešponduje to aj s výsledkami prieskumu Asociácie hudobných festivalov Českej republiky (Raabová a iní, 2012). Z nich vyplýva, že kým návštevníci desiatich skúmaných festivalov minuli na vstupenky 2,2 mil. eur, na stravovacie, ubytovacie, dopravné a d’alšie služby, využité v súvislosti s účast'ou na podujatí, vynaložili 2,1 mil. eur. Konštatujeme, že návštevníci festivalov zvyčajne minú na služby súvisiace s účast'ou na podujatí viac ako je cena vstupenky.

Napriek pomerne vysokým výdavkom, spojených s účast'ou na festivale, sa až 92,2\% respondentov vyjadrilo, že boli s podujatím nadmieru spokojní $(6,5 \%$ bolo skôr spokojných a 1,3\% sa nevedelo jednoznačne vyjadrit'). Najviac spokojní boli pritom s kvalitou programu a občerstvením. Festival plánuje v budúcnosti navštívit' až $90,9 \%$ respondentov $(33,1 \%$ určite a 57,8 \% skôr áno). Všetci respondenti sa zhodli na tom, že by svojim blízkym odporučili účast' na podujatí.

\subsection{Festival satiry a humoru Kremnické Gagy}

Výberový súbor v prípade analýzy uspokojeného dopytu po festivale Kremnické Gagy tvorilo 100 respondentov, z toho $64 \%$ žien. Najpočetnejšiu skupinu predstavovali 15 až 24 roční respondenti (34\%). Nasledovali respondenti vo veku 25 až 34 rokov (28\%), 45 až 54 rokov $(10 \%), 55$ až 64 rokov $(10 \%), 65$ a viac rokov ( $8 \%)$. Najmenej zastúpenou bola kategória detí do 14 rokov $(6 \%)$.

Najväčšia respondentov (36 \%) festival navštívila so svojou rodinou, necelá tretina (32\%) s priatel'mi a známymi, $28 \% \mathrm{~s}$ partnerom a len $4 \%$-tá prišli na podujatie sami.

Väčšina (72\%) respondentov sa na danom podujatí v minulosti zúčastnila. Až 38 \% podujatie navštívilo šest' a viackrát, pätina sa na predchádzajúcich ročníkoch zúčastnila jeden- až dvakrát, pre $18 \%$ išlo o prvú návštevu podujatia, $16 \%$ sa festivalu v minulosti zúčastnilo triaž štyrikrát a $8 \%$ pät'- až šest'krát. Konštatujeme, že väčšina respondentov patrí k stálym návštevníkom podujatia a že účast' na podujatí vyvoláva v návštevníkoch túžbu po jeho opätovnej návšteve. 
Kým viac ako štvrtina (26\%) respondentov sa $v$ mieste konania podujatia a jeho okolí obvykle zdržiava (býva, študuje alebo pracuje v Kremnici), zvyšných respondentov možno považovat' za návštevníkov v cestovnom ruchu, ktorí do Kremnice pricestovali primárne kvôli návšteve podujatia (52\%) alebo za iným účelom (22\%).

Respondenti sa na Festivale satiry a humoru zúčastnili predovšetkým kvôli (1) kultúrnemu obohateniu a objavovaniu, (2) úniku od všednosti, (3) neopakovatel'nej atmosfére a (4) sledovaniu zaujímavých výkonov účinkujúcich. Menej frekventovane uvádzali dôvody ako (5) potešenie zo spoločnosti iných l'udí, resp. družnost', socializácia, (6) získanie nových kontaktov či (7) vzdelávacia a intelektuálna hodnota. Kultúrne obohatenie a objavovanie považoval za dominantný motív účasti na podujatí $46 \%$ respondentov, $12 \%$ ho označilo za druhý najdôležitejší a $18 \%$ za tretí najdôležitejší motív návštevy podujatia. Únik od každodenného života bol naproti tomu dominantným motívom pre $10 \%$ respondentov, pre $30 \%$ išlo o druhý najdôležitejší a pre $20 \%$ o tretí najdôležitejší motív účasti na festivale. Neopakovatel'ná atmosféra prilákala na podujatie $26 \%$ respondentov, ktorí ju označili za dominantný motív, pre $12 \%$ išlo o druhý najdôležitejší podnet a pre $20 \%$ o tretí najdôležitejší podnet k návšteve podujatia.

Väčšina (64 \%) respondentov svoju účast’ na podujatí vopred plánovala, $36 \%$ sa o návšteve festivalu rozhodlo bezprostredne.

Takmer každý tretí respondent (28\%) sa pritom o účasti na podujatí rozhodol $v$ časovom predstihu ôsmych až 14 dní, takmer štvrtina (24\%) respondentov sa o návšteve festivalu rozhodla jeden až tri dni vopred, $22 \%$ sa rozhodlo štyri až sedem dní pred konaním podujatia, $16 \%$ v deň konania podujatia, $6 \%$ v dlhšom časovom predstihu (mesiac až dva dopredu) a len $4 \%$ sa rozhodlo 15 až 30 dní pred uskutočnením festivalu. Konštatujeme, že väčšina (78 \%) opýtaných jednotlivcov sa o účasti na Kremnických Gagoch rozhodla v časovom predstihu kratšom ako dva týždne.

Obrázok 3: Časový predtih rozhodovania o účasti na festivale

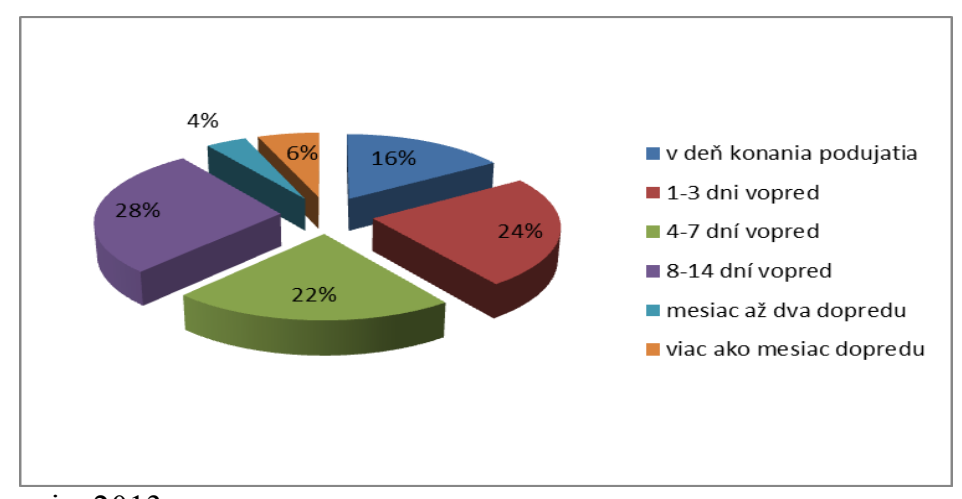

Zdroj: Vlastné spracovanie, 2013.

Za hlavný zdroj informácií o podujatí označilo $70 \%$ respondentov vlastnú predchádzajúcu skúsenost'. Konštatujeme teda, že v prípade festivalu Kremnické Gagy interný zdroj informácií prevažuje nad externým. Viac ako pätina (22 \%) sa o uskutočnení festivalu primárne dozvedela od priatel'ov, známych a príbuzných, t. j. zo spoločenských zdrojov, 4\% z propagačných materiálov a $4 \% \mathrm{z}$ internetu. 
Obrázok 4: Zdroj informácií o festivale

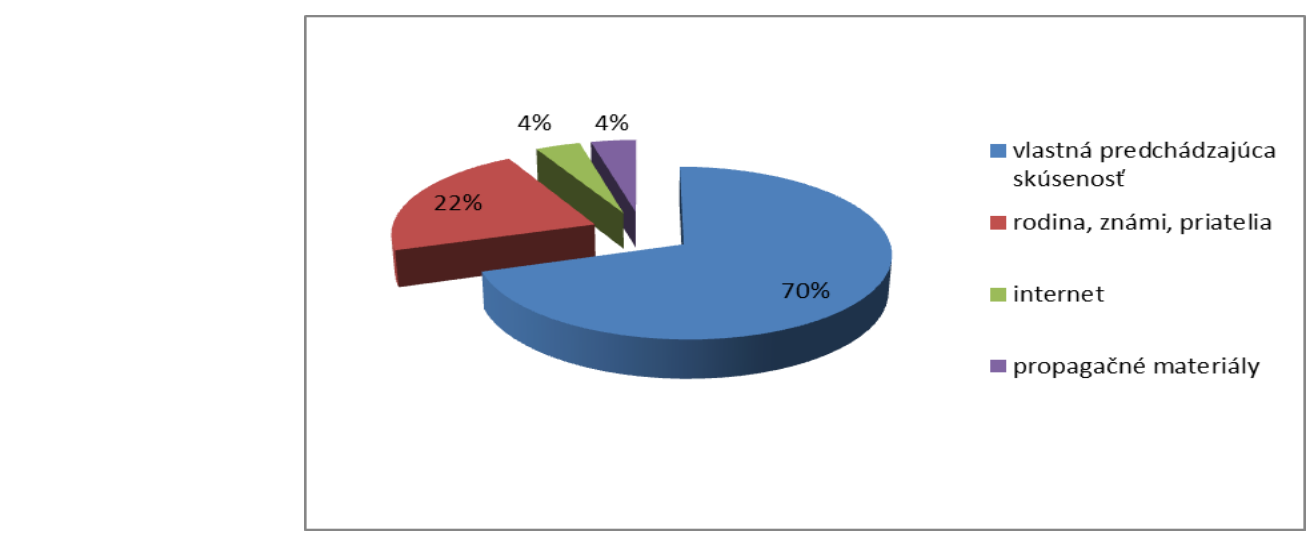

Zdroj: Vlastné spracovanie, 2013.

Všetci respondenti si svoju cestu na podujatie a služby s ňou spojené zabezpečovali individuálne, t. j. bez využitia služieb cestovných kancelárií či iných sprostredkovatel'ov.

Až $88 \%$ respondentov si vstupenku na podujatie kúpilo v pokladni v mieste konania podujatia, len $12 \%$ využilo možnost' zakúpenia vstupenky prostredníctvom internetových portálov. Ked’že vstup na viaceré predstavenia odohrávajúce sa na vol'nom priestranstve (na námestí, v uliciach) bol zdarma, 12 \% respondentov nevynaložilo na vstupenku žiadne peňažné prostriedky. Cena jednotlivých druhov predstavení v interiéri sa rôznila, najvyššia cena vstupenky na hlavné predstavenie, resp. produkciu pre dospelých bola pritom 13 eur, najnižšie vstupné bolo 5 eur. Cena vstupenky na detské predstavenia sa pohybovala do dvoch eur. $\mathrm{Aj} \mathrm{z}$ toho dôvodu $16 \%$ respondentov minulo na vstupenku na podujatie maximálne 10 eur, $44 \%$ vydalo na vstupenku od 10 do 20 eur. Ked’že návštevníci sa mali možnost' v priebehu festivalu zúčastnit' viacerých predstavení, $14 \%$ respondentov uviedlo, že vstupenky na vystúpenia ich stáli od 20 do 30 eur, $4 \%$ minuli na vstupenky od 30 do 40 eur a $10 \%$ od 40 do 50 eur (tabul'ka 48). Najčastejšie respondenti za vstupenku, resp. vstupenky na jednotlivé predstavenia vynaložili od 10 do 20 eur.

Až $60 \%$ respondentov na miesto konania podujatia precestovalo vzdialenost' kratšiu ako 20 $\mathrm{km}$ a d'alších $20 \%$ vzdialenost' 21 až $50 \mathrm{~km}$. Len $14 \%$ pricestovalo z miesta obvyklého pobytu vzdialeného 101 až $200 \mathrm{~km}, 4 \%$ prekonalo vzdialenost' 201 až $500 \mathrm{~km}$ a 2\% pricestovali zo vzdialenosti 51 až $100 \mathrm{~km}$. Ked'že až $70 \%$ respondentov prešlo vzdialenost' $50 \mathrm{~km}$ a menej konštatujeme, že daný festival oslovuje predovšetkým návštevníkov z okolitých miest a obcí, resp. z daného regiónu.

Najviac (62\%) respondentov prišlo do miesta konania podujatia vlastným automobilom, necelá štvrtina (24\%) autobusom, $12 \%$ vlakom a $2 \%$ prišli vzhl'adom na malú vzdialenost' od miesta obvyklého pobytu pešo.

Na dopravné služby respondenti minuli najčastejšie maximálne 10 eur, čo súvisí s blízkost'ou miesta obvyklého pobytu, z ktorého na podujatie pricestovali. Desatina respondentov uviedla, že na dopravu na podujatie nevynaložila žiadne prostriedky. Išlo o jednotlivcov, ktorí na podujatie prišli pešo $(2 \%)$ a tých, ktorí sa dopravili autom a prišli v sprievode svojich príbuzných a známych. Až $62 \%$ minulo na dopravu do 10 eur, $14 \%$ od 10 do 20 eur, $10 \%$ od 20 do 30 eur a $4 \%$ od 30 do 40 eur (tabul'ka 2). Išlo o jednotlivcov, ktorí na podujatie pricestovali zo vzdialenosti väčšej ako $50 \mathrm{~km}$. 
Ako vyplynulo $\mathrm{z}$ výsledkov skúmania, takmer žiadny z respondentov v mieste konania podujatia nevyužil služby ubytovacích zariadení. Po účasti na festivale sa väčšina (74 \%) vrátila do miesta svojho obvyklého pobytu, takmer štvrtina $(24 \%)$ respondentov prenocovala u priatel'ov, príbuzných a známych. Len $2 \%$ využili ubytovanie na súkromí, pričom za ubytovacie služby zaplatili do 10 eur. Konštatujeme teda, že festival je navštevovaný predovšetkým vo výletnom cestovnom ruchu.

Najviac (92\%) respondentov malo v súvislosti s účast'ou na festivale výdavky spojené so zabezpečením občerstvenia, resp. stravovania. Ako dokumentuje tabul'ka 2, $44 \%$ vynaložilo na stravovacie služby do 10 eur (usudzujeme, že využili služby zariadení poskytujúce doplnkové stravovanie), $36 \%$ od 10 do 20 eur, $10 \%$ od 20 do 30 eur a $2 \%$ od 30 do 40 eur.

Tovar súvisiaci s návštevou podujatia (upomienkový predmet) si kúpilo $58 \%$ respondentov. Kým $52 \%$ na jeho kúpu vynaložilo do 10 eur, $2 \%$ minulo 10 až 20 eur, $2 \% 20$ až 30 eur a rovnaký podiel (2\%) 30 až 40 eur (tabul'ka 2). Usudzujeme, že išlo o tovar dlhodobej spotreby, ktorý jednotlivcom pripomína miesto, kde si ho zakúpili.

Na kultúrne a spoločenské vyžitie v priebehu pobytu v mieste konania podujatia vynaložilo peňažné prostriedky len $36 \%$ respondentov. Takmer štvrtina $(24 \%)$ pritom minula maximálne 10 eur, $12 \%$ od 10 do 20 eur.

Väčšina (92\%) respondentov nemala s účastou na podujatí žiadne d’alšie výdavky, $8 \%$ vynaložilo na d'alšie tovary alebo služby v mieste konania podujatia do 10 eur (tabul'ka 2).

Tabul'ka 2: Výdavky respondentov na účast' na festivale Kremnické Gagy

\begin{tabular}{|l|c|c|c|c|c|c|c|}
\hline \multirow{2}{*}{ Výdavky na } & \multicolumn{7}{|c|}{ Podiel respondentov v \%, ktorí na podujatie vynaložili } \\
\cline { 2 - 8 } & $0 €$ & do $10 €$ & do $20 €$ & do $30 €$ & do $40 €$ & do $50 €$ & nad $50 €$ \\
\hline vstupenku & 12,00 & 16,00 & 44,00 & 14,00 & 4,00 & 10,00 & 0,00 \\
občerstvenie/ stravovanie & 8,00 & 44,00 & 36,00 & 10,00 & 2,00 & 0,00 & 0,00 \\
ubytovanie & 98,00 & 2,00 & 0,00 & 0,00 & 0,00 & 0,00 & 0,00 \\
dopravu & 10,00 & 62,00 & 14,00 & 10,00 & 4,00 & 0,00 & 0,00 \\
Suveníry & 42,00 & 52,00 & 2,00 & 2,00 & 2,00 & 0,00 & 0,00 \\
kultúrne a spoločenské vyžitie & 64,00 & 24,00 & 12,00 & 0,00 & 0,00 & 0,00 & 0,00 \\
iné & 92,00 & 8,00 & 0,00 & 0,00 & 0,00 & 0,00 & 0,00 \\
\hline Spolu & 0,00 & 2,00 & 6,00 & 10,00 & 4,00 & 16,00 & 62,00 \\
\hline
\end{tabular}

Zdroj: Vlastné spracovanie, 2013.

Konštatujeme, že účast' na festivale Kremnické Gagy je spojená s viacerými výdavkami návštevníkov, z ktorých značná čast' plynie subjektom pôsobiacim v ciel'ovom mieste. Návštevníci najčastejšie vynakladajú prostriedky na zabezpečenie stravovacích, dopravných služieb a kúpu vstupenky, resp. vstupeniek na predstavenia. V priemere najviac míňajú na vstupenky (od 10 do 20 eur), a to aj napriek tomu, že na niektoré predstavenia je počas festivalu vstup vol’ný. V štruktúre ich výdavkov majú významné postavenie aj stravovacie a dopravné služby. Celkové výdavky respondentov na účast' na festivale v prípade $62 \%$ presiahli 50 eur, pričom maximálny zaznamenaný výdavok sa pohyboval okolo 100 eur. Necelá šestina respondentov (16\%) minula od 40 do 50 eur, $10 \%$ od 20 do 30 eur, $6 \%$ od 10 do 20 eur, $4 \%$ od 30 do 40 eur a $2 \%$ maximálne 10 eur.

S podujatím bolo $48 \%$ skôr spokojných a $38 \%$ úplne spokojných. Zvyšných $14 \%$ nevedelo svoju spokojnost' posúdit'. Najspokojnejší boli pritom respondenti s kvalitou programu (54\% 
úplne spokojných, 42 \% skôr spokojných, 2 \% skôr nespokojných). V budúcnosti plánuje festival navštívit' 94 \% (56 \% určite a 38 \% skôr áno). Všetci opýtaní jednotlivci by pritom svojim blízkym odporučili návštevu daného podujatia.

\subsection{Podujatie „,Tanečný koncert"}

Fuzáková Dvorožňáková (2009) v júni 2008 uskutočnila na vzorke 92 respondentov (ženy: 63 \%, muži: $37 \%$; 15-18 roční: 4,3 \%, 19-24 roční: 14,1 \%, 25-39 roční: 23,9 \%, 40-59 roční: 39,2 \%, 60 a viacroční: 18,5 \%) prieskum uspokojeného dopytu návštevníkov Tanečného koncertu. Ide o dvojhodinové každoročne sa opakujúce podujatie, ktoré prezentuje tanečné kompozície a formácie, detské hry a tance žiakov Súkromnej základnej umeleckej školy.

Autorka (Fuzáková Dvorožňáková, 2009) zistila, že len necelá tretina $(32,6$ \%) respondentov navštívila podujatie prvýkrát, zvyšná čast' sa na podujatí v minulosti aspoň raz zúčastnila. Predpokladáme, že dôvodom bolo to, že dotazníkom oslovila nielen divákov, ale aj účinkujúcich $(15,2 \%)$ a organizátorov $(8,7$ \%). Navyše, usudzujeme, že čast' návštevníkov sa na podujatí zúčastňuje kvôli programu, v ktorom účinkujú ich deti, resp. príbuzní a známi. Ked’že cena vstupeniek na podujatie je diferencovaná z hl'adiska veku návštevníkov (dospelí, deti, seniori), minimálne výdavky na zabezpečenie vstupenky boli 2 eurá, maximálne 11,95 eur. Priemerné výdavky za vstupné na všetkých respondentov boli 4,39 eur a len na platiacich respondentov 6,03 eur.

Ako uvádza Fuzáková Dvorožňáková (2009), až 50 \% respondentov uviedlo, že sa pre návštevu podujatia rozhodli na základe vlastnej skúsenosti, t. j. informácie o podujatí čerpali $\mathrm{z}$ interných zdrojov. Druhým najdôležitejším zdrojom informácií boli pritom odporúčania priatel'ov, príbuzných a známych (spoločenské zdroje).

Ked’že podl'a výsledkov prieskumu (Fuzáková Dvorožňáková, 2009) sa viac ako polovica $(54,3 \%)$ respondentov ubytovala vo vlastnom dome alebo byte usudzujeme, že väčsina návštevníkov podujatia pochádza z miesta konania podujatia (Liptovského Hrádku), prípadne z blízkeho okolia. Len necelá tretina (32,6 \%) respondentov využila služby komerčných ubytovacích zariadení, 10,9 \% nocovalo u známych. Až 94,6 \% opýtaných uviedlo, že pri opakovanej návšteve podujatia by sa ubytovali v tom istom zariadení, z čoho vyplýva, že s poskytnutými ubytovacími službami boli spokojní. Respondenti, ktorí sa v súvislosti s pobytom $\mathrm{v}$ mieste konania podujatia ubytovali $\mathrm{v}$ komerčnom zariadení za ubytovanie v priemere zaplatili 30,18 eur.

Až 43,5 \% respondentov sa stravovalo v reštaurácii, 25 \% si zabezpečilo stravu individuálne a $13 \%$ sa stravovalo u príbuzných. Všetci respondenti boli pritom so stravovacími službami spokojní (60,9 \% úplne, 39,1 \% čiastočne). Ked’že Fuzáková Dvorožňáková (2009) skúmala priemerné výdavky respondentov na zabezpečenie celodennej stravy $(13,99$ eur) napriek tomu, že podujatie trvalo len dve hodiny a väčšina respondentov pochádzala $\mathrm{z}$ miesta konania podujatia, resp. z jeho okolia, výdavky na stravovacie služby súvisiace s účast'ou na podujatí nie je možné kvalifikovane odhadnút'.

$\mathrm{Na}$ podujatie sa respondenti dopravili prevažne vlastným automobilom $(59,8 \%)$. Vlakom pricestovalo $14,1 \%$ respondentov, zájazdovým autobusom prišlo $10,9 \%$, pravidelnou autobusovou linkou 7,9 \% a pešo, prípadne iným spôsobom 7,6 \%. Priemerné výdavky za dopravu boli 19,71 eur. Ako sa zmieňuje Fuzáková Dvorožňáková (2009), v blízkosti miesta, kde sa podujatie konalo, sú tri rôzne parkoviská, jedno je strážené a platené, dve nestrážené a bez poplatku. Ani jeden z respondentov nemal výdavky za parkovacie miesto. 
Fuzáková Dvorožňáková (2009) d’alej zist'ovala, aké mali návštevníci výdavky za rôzne tovary a služby, ktoré nakúpili počas podujatia. Ich priemerné výdavky boli 9,07 eur.

Autorka porovnávala celkové výdavky jednotlivých kategórií respondentov. Za celkové výdavky pritom považovala úhrn výdavkov za ubytovanie, zabezpečenie celodennej stravy, dopravy na miesto podujatia, výdavky na parkovanie, vstupenku, výrobky, tovary alebo služby zakúpené na podujatí. Kým zamestnaní minuli na podujatí priemerne 78,38 eur, nezamestnaní len 9,29 eur, študenti 7,19 eur a dôchodcovia 9,55 eur (Fuzáková Dvorožňáková, 2009). Usudzujeme, že kategória zamestnaných respondentov do svojich výdavkov započítala aj výdavky na obstaranie tovarov a služieb celej rodiny vrátane detí.

Najvyššie celkové priemerné výdavky mala veková skupina 40 až 59-ročných (97,46 eur), nasledovala veková skupina 25 až 39-ročných (53,08 eur), veková skupina 19 až 24-ročných (14,99 eur), veková skupina 60 a viacročných (9,55 eur) a veková skupina 15 až 18-ročných (7,55 eur) (Fuzáková Dvorožňáková, 2009), ktorí sú bez pravidelných príjmov.

Vysokoškolsky vzdelaní návštevníci mali najvyššie priemerné výdavky $(79,64$ eur), nasledovali stredoškolsky vzdelaní návštevníci s maturitou (40,16 eur), stredoškolsky vzdelaní návštevníci bez maturity (14,37 eur) a návštevníci so základným vzdelaním $(6,09$ eur) (Fuzáková Dvorožňáková, 2009).

Celkové výdavky respondentov a ich štruktúra závisela od toho, či pochádzali z miesta konania podujatia, a či platili vstupné na podujatie (alebo boli účinkujúcimi, organizátormi). Cena za d'alšie tovary a služby však vo všeobecnosti prevýšili cenu vstupenky. Vyplýva $\mathrm{z}$ toho, že aj podujatia prevažne miestneho významu generujú pozitívne ekonomické účinky na ciel'ové miesto, v ktorom sa konajú.

Až 98,9 \% respondentov sa vyjadrilo, že návštevu podujatia odporučí svojim priatel'om a známym, a to pre spokojnost' $\mathrm{s}$ hodnotným programom a dobrou organizáciou $(98,9 \%)$, pekným prostredím podujatia (59,8 \%), kvalitnými službami $(91,3 \%)$, s dobrou dostupnostou miesta $(76,1 \%)$, s primeranými cenami $(85,9 \%)$ a inými dôvodmi $(96,7 \%)$ ako napríklad výborní tanečníci, kontakt s folklórom, kultúrny zážitok, priatel'skí l'udia ap. (Fuzáková Dvorožňáková, 2009).

\section{Záver}

Ciel'om state bolo zhodnotit' a porovnat' efektívny dopyt po vybraných podujatiach na Slovensku. Analyzovali sme dopyt po hudobnom festivale Bažant Pohoda, ktorý patrí $\mathrm{k}$ podujatiam s národným významom, po Festivale satiry a humoru Kremnické Gagy, ktorý má prevažne regionálny význam, a po podujatí miestneho významu „Tanečný koncert“. Dotazníkom sme oslovili 154 respondentov, ktorí sa v minulosti zúčastnili hudobného festivalu Bažant Pohoda v Trenčíne a 100 respondentov, ktorí navštívili Festival satiry a humoru Kremnické Gagy v Kremnici. Informácie o dopyte po podujatí Tanečný koncert, sme získali zo sekundárnych zdrojov.

Za úskalie realizovaného prieskumu považujeme relatívne malý počet respondentov, absenciu informácií o základnom súbore a heterogénnost' ponuky skúmaných kultúrnych podujatí. Pri d’alšom skúmaní vybranej problematiky by bolo vhodné úzko kooperovat' s organizátormi vybraných podujatí. 
Zistili sme, že prestížny hudobný festival Bažant Pohoda navštevujú najmä mladí l’udia vo veku od 15 do 34 rokov, ktorí na podujatie prichádzajú s priatel'mi. Väčšina respondentov sa podujatia zúčastnila po prvýkrát, čo súvisí s vysokou cenou vstupenky a vzdialenost'ou miesta, kde sa podujatie koná. Do Trenčína cestovali primárne kvôli návšteve vybraného festivalu. Dozvedeli sa o ňom s elektronických zdrojov, svoju účast' na podujatí dlhodobo plánovali (viac ako mesiac dopredu) a vstupenku si zákúpili prostredníctvom internetu. $\mathrm{Na}$ festivale strávili viac ako jeden deň, pričom väčšina prenocovala v stanovom mestečku. Motívom návštevy podujatia bolo sledovanie zaujímavých vystúpení a jedinečnost' hudobného festivalu, ktorý patrí medzi najlepšie v strednej Európe. Napriek vysokej cene vstupenky a d'alším výdavkom na stravovanie, dopravu, suveníry a d'alšie tovary a služby, boli s podujatím väčšinou úplne spokojní a odporučili by ho svojim priatel’om a známym.

Festival satiry a humoru Kremnické Gagy v Kremnici zhodne navštevujú najmä mladí l'udia do 34 rokov. Tí však na podujatie prichádzajú najmä so svojou rodinou, a to opakovane, za účelom kultúrneho obohatenia a úniku od všednosti. Informácie o festivale čerpajú najmä z vlastných predchádzajúcich skúseností, o jeho návšteve sa rozhodujú menej ako dva týždne vopred a vstupenku na jednotlivé vystúpenia si kupujú na mieste - v pokladni. Väčšina návštevníkov prichádza na festival z Kremnice alebo jej okolia, a to vlastným autom, pričom sa $\mathrm{v}$ ten istý deň vracia do miesta svojho obvyklého pobytu. S podujatím boli návštevníci väčšinou skôr spokojní.

Podujatie miestneho významu Tanečný koncert navštevujú najmä l'udia v strednom veku (40 až 59 roční). Na podujatie väčšinou prichádzajú opakovane, a teda informácie o ňom čerpajú z interných zdrojov (t. j. z vlastnej skúsenosti). Väčšina návštevníkov pochádza z miesta, kde sa podujatie koná a vzhl'adom na dížku jeho konania (2 hodiny) sa po jeho skončení a návšteve reštaurácie vracia autom domov. Aj v prípade Tanečného koncertu sú výdavky návštevníkov na d’alšie služby spojené s návštevou podujatia väčšie, ako je samotná cena vstupenky na podujatie. Jej výška je však niekol'konásobne nižšia ako cena vstupeniek významnejších podujatí.

Z porovnania dopytu po vybraných kultúrnych podujatiach rôzneho významu vyplynulo niekol'ko rozdielov. Kým podujatie väčšieho významu s vyššou priemernou cenou vstupenky jednotlivci navštívili prevažne po prvý krát, svoju účast' plánovali v dostatočnom časovom predstihu a na festival pricestovali $\mathrm{z}$ väčšej vzdialenosti, podujatí s menším (regionálnym a miestnym) významom sa respondenti zúčastňujú pravidelnejšie, čo súvisí nielen s nižším priemerným vstupným, ale aj s blízkost'ou miesta konania podujatia. Podujatia s menším významom v cestovnom ruchu pritom navštevujú predovšetkým obyvatelia $\mathrm{z}$ daného regiónu, ktorí sa o účasti na podujatí rozhodujú v kratšom časovom predstihu. Ako sa zmieňujú napr. Coopers, Lybrand (1989 In Getz, 2012) a McHone, Rungeling (1999) pre rezidentov je podujatie menej výnimočné, pretože sa ho majú možnost' zúčastnit' viackrát. Ich ochota platit' za účast' na podujatí je menšia, t.j. aj ich výdavky spojené s účast'ou na podujatí sú pre miestnu ekonomiku menej stimulujúce.

Kým o podujatí národného významu sa jednotlivci dozvedajú najmä z externých zdrojov, informácie o podujatí menšieho významu čerpajú najmä z interných zdrojov (z vlastnej skúsenosti). Účast' na významnejšom podujatí súvisí s vyššími výdavkami návštevníkov nielen na vstupenku, ale aj na stravovacie, dopravné, ubytovacie a iné služby a tovary. Tie, predpokladáme, plynú najmä subjektom podnikajúcim v mieste konania podujatia, čím sa podporuje miestna ekonomika a podnecuje d'alší rozvoj územia. 


\section{Pod'akovanie}

Príspevok je súčast'ou riešenia projektu VEGA 1/0810/13 Predpoklady uplatnenia koncepcie spoločensky zodpovedného správania $\mathrm{v}$ cestovnom ruchu v SR, ktorý sa rieši na Ekonomickej fakulte Univerzity Mateja Bela v Banskej Bystrici.

\section{Literatúra}

[1] Bažant Pohoda: Návštevník minie na festivale v priemere $40 €$ [online]. [vid. 2013-0319]. Dostupné z: https://www.slsp.sk/Clanok/sk/bazant-pohoda-navstevnik-minie-nafestivale-v-priemere-40-eur/bazant_pohoda_navstevnik_minie_na_festivale_v_priemere_ 40_\%E2\%82\%AC.htm

[2] FRECHTLING, D. C., 2012. Forecasting Tourism Demand: Methods and strategies. Oxford: Butterworth-Heinemann. ISBN 0-7506-5170-9.

[3] FUZÁKOVÁ DVOROŽŇÁKOVÁ, M., 2009. Ekonomické a sociálne účinky vybraného organizovaného podujatia. In: Cestovný ruch - teória a prax v podmienkach globalizácie. Banská Bystrica: Ekonomická fakulta UMB, 2009, s. 88-96. ISBN 978-80-8083-744-0.

[4] GETZ, D., 2012. Event studies. Theory, research and policy for planned events. Druhé vydanie. Oxon; New York: Routledge, 2012. ISBN 978-0-08-096953-4.

[5] GÚČIK, M., 2010. Cestovný ruch. Úvod do štúdia. Knižnica cestovného ruchu 15. Banská Bystrica: Slovak-Swiss Tourism, 2010. ISBN 978-80-89090-80-8.

[6] HOREHÁJOVÁ, M. a J. MARASOVÁ, 2007. Základy mikroekonómie. Banská Bystrica: Ekonomická fakulta Univerzity Mateja Bela, 2007. ISBN 978-80-8083-536-1.

[7] KASPAR, C., 1995. Základy cestovného ruchu. Knižnica cestovného ruchu 1. Banská Bystrica: Ekonomická fakulta UMB, 1995. ISBN 80-901166-5-5.

[8] LIM, Ch., 1997. Review of international tourism demand models. Annals of tourism research, 24(4), 835-849. ISSN 0160-7383.

[9] MCHONE, W. W. and B. RUNGELING, 1999. Special cultural events: do they attract leisure tourists? Hospitality management, 18(2), 215-219. ISSN 0959-6119.

[10] MUCHOVÁ, E., 2003. Dopyt, ponuka a rovnovážna cena. In: J. LISÝ a iní. Ekonómia. V̌̌eobecná ekonomická teória. Piate prepracované a doplnené vydanie. Bratislava: Iura edition, s. 76-92. ISBN 80-89047-75-0.

[11] PAULIČKA, I. a iní, 2002. Všeobecný encyklopedický slovník A-F. Praha: Ottovo nakladatelství. ISBN 80-7181-618-3.

[12] RAABOVÁ, T. a iní, 2012. Analýza ekonomického dopadu. Asociace hudebníchfestivali̊ České republiky. Praha: Economic impact. ISBN 978-80-260-1727-1.

[13] SWARBROOKE, J. and S. HORNER, 2001. Business travel and tourism. Oxford: Butterworth Heinemann. ISBN 0-7506-43927. 